\title{
The influence of store environment on brand attitude, brand experience and purchase intention
}

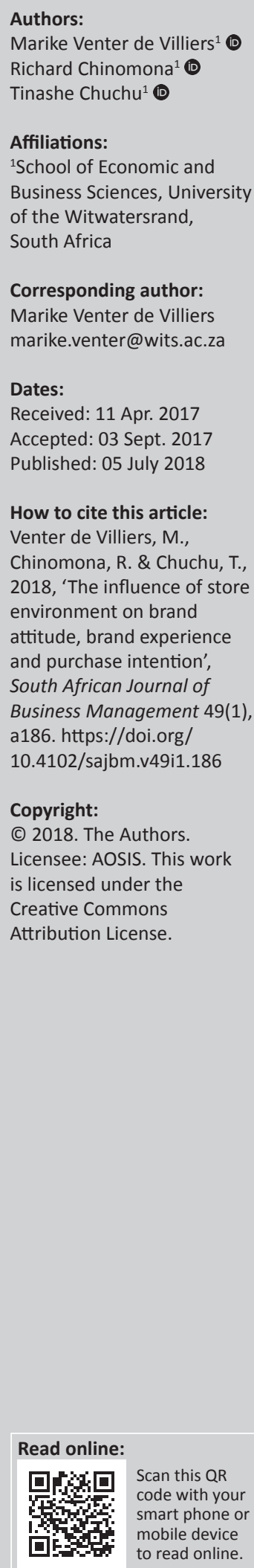

Background: Consumer decision-making is shifting from the rational to the emotional, and as a result, retailers are investing in unique store atmospheric cues to capture the attention of consumers. Although not a completely new phenomenon, a lack of studies on this topic remains in Africa, an emerging economy that is rapidly becoming part of the global economy. This is especially evident in the fashion industry where global fashion chain stores are rapidly infiltrating the local market.

Objectives: This article aims to investigate the influence of store environment on purchase intention of fashion products with brand attitude and brand experience as the mediators.

Method: By means of a quantitative study, 501 online self-administered surveys were distributed among black middle-class women residing in Johannesburg.

Results: The results support four of the five hypotheses. It is therefore evident that store environment positively influences consumer's brand attitudes, purchase intention and brand experience in the fashion retail industry.

Conclusion: This article contributes to existing literature on fashion retail, experiential marketing and branding. It further provides retailers with adequate insight into experiential retail strategies that can yield profitable returns and increase their customer loyalty base.

\section{Introduction}

Consumer decision-making is increasingly driven by emotional factors rather than rational factors, and as a result, retailers are investing in experiential marketing strategies to drive sales (Clarke, Perry \& Denson 2012; Kim, Koo \& Chang 2009). Consumers are therefore also considering the experience they receive when buying a product or a service, rather than only making a decision based on functional benefits. This characteristic of consumers ultimately guides marketers to implement innovative retail strategies, in order to build customer loyalty on the foundation of experiential marketing. Thus, retailers ought to create a unique in-store experience so as to differentiate themselves from competitors. This is especially relevant to fashion retailers, as the instore fashion-brand experience is a multifaceted experience that positively influences customerbased brand equity (Kim 2012; Michon et al. 2007). The fashion industry has experienced substantial economic growth as it is largely driven by exports to emerging countries (Iannone et al. 2013).

Furthermore, women spend an average of $70 \%$ of their income on clothing and therefore regarded as the primary customer base in the fashion industry (Arnold \& Reynolds 2003; Babin, Hardesty \& Suter 2003). As a result, the growing numbers of young professional female consumers have become a segment of major importance and interest to marketers (Arnold \& Reynolds 2003; Babin et al. 2003). The importance of this market segment has received an abundance of interest from practitioners, as they have doubled in size over the past 8 years. Further to this, the black middleclass is currently estimated to comprise about 4.2 million people in South Africa (Unilever Institute of Strategic Marketing 2013).

Given the importance of the fashion retail sector to women, this study aims to investigate the influence of store environment on purchase intention among black middle-class women in Johannesburg. By gaining insight into this topic, retailers are given the opportunity to provide a differentiated in-store experience by means of which to attract consumers (Clarke et al. 2012).

A number of studies have been conducted on this topic; however, the vast majority focused on single elements of store environment such as sight, sound or touch (Clarke et al. 2012; Park, Jeon \& Sullivan, 2014; Valenti \& Riviere 2008), rather than store environment as a holistic construct that incorporates a number of sensory cues. Furthermore, Clarke et al. (2012) have examined the 
impact of store environment on the time spent in a store (2011), whereas Tendai and Crispen (2009) have found store environment to promote impulse buying. Furthermore, a positive relationship was found between visual merchandising and brand attitude and purchase intention, respectively (Park et al. 2014).

By means of a proposed conceptual model, this study investigates the relationship between store environment and purchase intention, with brand attitude and brand experience as the mediators. More specifically, this study aims to provide insight into these relationships among black middle-class women in Johannesburg with relation to fashion brands. In practice, this means that the more pleasant an in-store environment is, the more likely that consumers will portray positive attitudes towards the brand, have a positive brand experience and ultimately purchase a product. It is therefore argued that by creating an exceptional sensory experience, fashion retailers are able to influence consumer's buying behaviour, which will ultimately lead to an increase in sales.

This article is structured in the following way: Firstly, a theoretical overview is provided, followed by the research design and methodology; thereafter, the results are presented, followed by the discussions; and lastly, the implications, limitations and future research is discussed.

\section{Theoretical framework}

This study is grounded in Schmitt's (1999) experiential branding model and Hultén's (2011) multi-sensory brand experience model. The following section provides an overview of the theoretical terms underlying this study.

\section{Experiential branding model}

The first model that grounds this study is Schmitt's (1999) experiential branding model. This comprises a fivedimensional framework for experiential branding, which covers sensory experience, affective experience, intellectual experience, behavioural experience and social experience. According to Schmitt (1999), these dimensions are evoked by various stimuli, including the brand's design, packaging, environment and communications. Firstly, the sensory experience refers to the visual, auditory, tactile, atmospheric and gastronomic experiences that a customer has when they interact with the marketing environment. The affective dimension is the emotions, which are evoked when immersed in the environment. Further, the intellectual (or cognitive) aspect of the experiential branding model refers to the customer's reasoning about the marketing environment with which they engage (Schmitt 1999). An environment that provides a strong cognitive experience is able to effectively communicate messages to the client about different positive elements in relation to visiting and making purchases in the store (Brakus, Schmitt \& Zarantonello 2014). The fourth experience that the model comprises is the dimension of behaviour. The latter dimension is concerned with customers' experiences with the dynamics of the marketing environment.
Lastly, the social experience concerns the nature and quality of relationships formed in the store environment, both between customers and employees, and among the different customers in the store. The basis of this model correlates with this study's conceptual model in the following ways: both are grounded in the concept of sensory branding and the way in which the servicescape (store design and layout, interaction with other customers, the service process and customer service) influences consumers' affective and cognitive behaviour.

\section{Multi-sensory brand experience model}

Hultén (2011) developed a multi-sensory brand experience model based on the argument that stores should make use of diverse sensorial strategies in order to differentiate its brand and connect with its target markets. According to Hultén (2011), the five senses (smell, sound, sight, taste and touch) play important roles in customer experience when visiting a store. The importance of each of the senses may differ, depending on the product or service that a store is selling (Hultén 2011; Hulten, Broweus \& Van Dijk 2009). For example, a bakery may focus on the smell of bread, which is a strong tangible means to compel visitors to enter the store. Likewise, a coffee brewery will benefit from the attraction of the smell of coffee, whereas a clothing store might consider a fragrance or an earthy smell. Further, the importance of sound in terms of type of music, as well as the volume, will differ according to the kind of product being sold and the relevant target market. However, by utilising sensory branding, retailers can gain tremendously in terms of sales and profits. The application of this model to this study is as follows: in a similar way to the aforementioned model, the majority of these sensations are incorporated into the 'store environment' construct (atmospherics, visual and auditory sensations), while the gastronomic sensation (taste) is less relevant to fashion and has therefore been omitted.

\section{Store environment}

Store environment is a critical aspect of marketing and refers to the physical environment of a store, such as the music, lighting, store layout and arrangement of merchandise (Hu \& Jasper 2006; Wang \& Ha 2011). Aspects of the store environment have been found to have a significant influence on a store's financial performance (Lam 2001). Likewise, the store environment can elicit a wide range of behaviours from people within the store (Geetha, Bharadhwaj \& Piyush 2013), where certain elements can influence customers to stay in the store longer, increasing the probability that they may buy an item. Conversely, store elements can also have a negative effect on consumer's behaviour by influencing them to leave the premises prematurely.

\section{Brand attitude}

Brand attitude refers to the direction and strength of the perception that consumers have in relation to a brand (Yoon \& Park 2012). By gaining insight into brand attitude, marketers are able to determine customers' brand perceptions and 
ascertain their willingness to make a purchase. A customer's brand attitude also tends to reveal his or her predisposition to recommending the brand to others (Tong \& Hawley 2009). Yoon and Park (2012) found that sensory advertisements have significant impacts on brand attitudes. In particular, some ads allow consumers to associate with the brand and therefore to view the brand positively (Yoon \& Park 2012). On the contrary, consumers who find some ads offensive or ludicrous tend to transfer these perceptions onto the brand itself (Yoon \& Park 2012). Brand attitudes are therefore an important measure in determining possible buying behaviour among current and potential customers.

\section{Brand experience}

Brand experience is another important category in the fashion retail industry and is defined by Brakus, Schmitt and Zarantonello (2009) as the totality of subjective, internal consumer responses, such as sensations, feelings and cognitions that are evoked by brand-related stimuli. It is further defined as the overall impact that a brand has on a customer, which is derived from the combination of the different marketing elements that are put together in order to communicate the brand (Shamim \& Butt 2013). The brand experience is often regarded as the sensory embodiment of the brand (Hultén 2011) and refers to how the brand connect with the five different senses of consumers, from how the logo of the brand appears to people, to how appealing the ambience is to people who visit the stores where products of the brand are sold. A number of studies have found that brand experience has a significant influence on brand loyalty (Brakus et al. 2009; Gentile, Spiller \& Noci 2007; Ghodeswar 2008; PonsonbyMcCabe \& Boyle 2006; Schmitt 2009).

\section{Purchase intention}

Purchase intention refers to a consumer's plan to buy a product or engage in a service while it involves the particular circumstances and timing in which the consumer will buy an item (Lu, Chang \& Chang 2014). Such buying behaviour is usually driven by a certain need or compulsion that arises, or if the item's prices reaches a certain desirable level ( $\mathrm{Lu}$ et al. 2014). Purchase intention is commonly measured using three dimensions, such as priority, periodicity and spontaneity (Anderson et al. 2014; Ko \& Megehee 2012; Moore 2014). Priority items entail goods that are highly prioritised such as food and petrol, whereas periodicity refers to how often the consumer intends to purchase the product. Some products have very high periodicity, which means that consumers purchase them at predictable intervals of time (Moore 2014). Lastly, spontaneity refers to the length of time between the customer's decision to buy a product and the actual execution of the intention (Moore 2014).

\section{Conceptual model and hypotheses development}

By means of a conceptual model, the following is proposed: firstly, store environment represents the predictor variable,

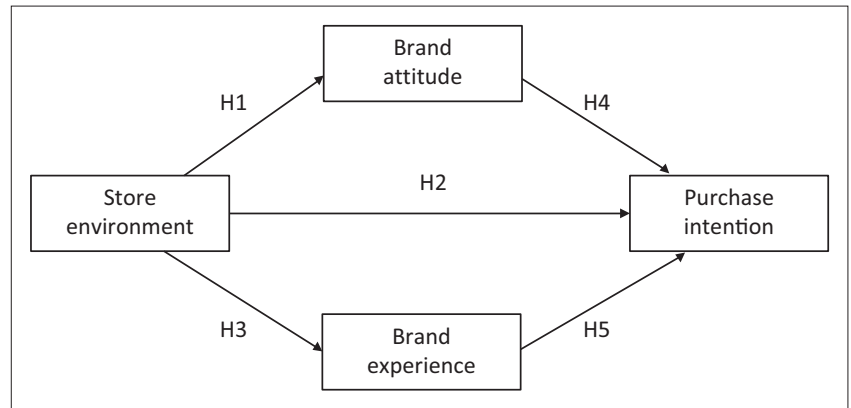

FIGURE 1: Conceptual model.

with purchase intention as the outcome variable. There are two mediators, namely brand attitude and brand experience. This model therefore proposes that a feasible store environment will positively influence consumer's brand attitudes, their brand experience and ultimately their purchase intention of fashion products. Figure 1 presents the proposed conceptual model for this study, followed by the hypotheses development.

\section{Hypotheses development}

\section{Store environment and brand attitude (H1)}

It is essential to note the important impact that store environment has on a customer's attitude towards the retail brand. Research on the matter has been investigated in a number of studies, where the majority of these studies have produced consistent findings. Brand attitude stimulates an individual's subconscious and tends to impact their decisions about the brand, often without them even noticing (Zenker \& Rütter 2014). Studies previously discussed include those by Lunardo and Mbengue (2013) and Kumar and Kim (2014), which both identified certain particular store environmental characteristics as having important positive impact on consumer's attitude towards a given brand. In particular, Kumar and Kim (2014) discussed that consumers tend to develop negative attitudes towards the brand when elements in the store environment imply that the store is attempting to mislead the consumer in some way. The relationship between these two variables is more closely examined in Vieira (2013), who conducted a meta-analysis of research studies that have examined store environment and brand attitude over the past two decades. According to Vieira (2013), it is evident from previous research that there exists a stimuli-organismresponse framework governing the relationship between the two variables, in which consumers that experience certain elements of the store environment tend to associate this with the quality of the brand, and so their attitude about the brand can shift, depending on stimuli that they encounter during their in-store experiences.

$\mathrm{H} 1$ : There is a positive relationship between store environment and brand attitude.

\section{Store environment and purchase intention (H2)}

Other studies focused on the effects of store environments on particular actions of shoppers. For example, a number of studies have focused the impact of different store environment 
elements on impulse buying behaviour, and it was found that various visual and auditory cues, which generate sudden interest or cognitively persuade customers about certain needs, can act as triggers for impulse buying (Dawson \& Kim 2009; Geetha et al. 2013; Hyo, Ruoh-Nan \& Molly 2014; Tendai \& Crispen 2009). In Tendai and Crisper (2009) specifically, it was found that impulse buying was more likely to occur from in-store settings of an economic nature, rather than other atmospheric factors. There are also studies that considered the effect of store environments on general marketing strategies, such as relationship marketing (Wang \& Ha 2011), or on store image (Hu \& Jasper 2006). In relationship marketing, certain store environment settings were found to be more conducive to relationship building between sales representatives and customers, than were others. Typically, environments that influence shoppers to stay longer in the store help sales representatives to establish stronger relationships with them, which translate to higher rates of repeat business from such customers.

$\mathrm{H} 2$ : There is a positive relationship between store environment and purchase intention.

\section{Store environment and brand experience (H3)}

The relationship between store environment and brand experience has been explored in such studies as those conducted by Kumar and Kim (2014), and Holmqvist and Lunardo (2015). Kumar and Kim (2014) explored the relationship between consumers internal evaluations of a brand on such consumers' perception of the store environment and found that when consumers' initial perceptions of the environment are negative, there is a tendency for them to rate their overall brand experience as less fulfilling than those who perceived the store environment positively. The social environment, design and ambient cues in the store were found to significantly influence consumers' brand experience, thereby establishing the importance of the store environment in developing brand experience (Kumar \& Kim 2014). Similarly, Holmqvist and Lunardo (2015) found that exciting store environments tend to elevate consumer pleasure with their brand experience. Besides the proper design of a store, good lighting and enticing visual cues, retailers can create a pleasant store environment by implementing customer experience management (CEM) (Kamaladevi 2010). A successful application of this results in a win-win value exchange between the customer and the retail brand (Kamaladevi 2010). In other studies on store environment and brand experience (Holmqvist \& Lunardo 2015; Kumar \& Kim 2004), in-store design is shown to play an important role in shaping consumers' perception of the brand, which can result in consumers' purchasing the brand and ultimately becoming brand loyal. Furthermore, the social environment, design and ambient conditions have been found to significantly influence consumer's brand experience, thereby establishing the importance of the store environment in developing brand experience (Kumar \& Kim 2014). Similarly, Holmqvist and Lunardo (2015) found that exciting store environments tend to elevate consumer sense of pleasure with their brand experience. Beverland et al. (2006) focused on in-store music and found that consumers were able to distinguish between in-store music that fit well with the brand of the store in which they were browsing and that which did not.

H3: There is a positive relationship between store environment and brand experience.

\section{Brand attitude and purchase intention (H4)}

Rationally, the relationship between brand attitude and purchase intention is not difficult to consider. As discussed by Brakus et al. (2009), brand attitude is evoked from brand experience, where consumers determine whether or not they like a brand based on their experience with it. As such, purchase intention may be regarded as related to brand attitude just as brand experience has been known to be (Anderson et al. 2014; Barnes, Mattsson \& Sørensen 2014; Hung et al. 2011). Wu and Lo (2009) examined the impact of brand attitude on purchase intention among consumers looking to purchase personal computers in Taiwan. From a sample of 667 respondents, brand attitude was shown to have causal impacts on purchase intention (Wu \& Lo 2009). The study found that first and foremost, consumers tended to select brands with which they were familiar. At the same time, they avoided brands towards which they had negative attitudes. Conversely, they tended to select brands that they liked, based on how they perceived the image of the brand from various direct and indirect stimuli $(\mathrm{Wu} \& \mathrm{Lo}$ 2009). In another study, Jin and Kang (2011) examined the purchase intentions of Chinese consumers of US apparel brands and found from a survey of 747 consumers that increased positive attitude towards US apparel brands greatly explains consumers' preference for such brands over locally branded or unbranded apparel. This study proposes that a positive relationship exists between brand attitude and brand loyalty.

H4: There is a positive relationship between brand attitude and purchase intention.

\section{Brand experience and purchase intention (H5)}

The influence of brand experience on purchase intention has also yielded interest from several researchers. For example, the link between brand experience and purchase intention is widely researched in marketing literature (Anderson et al. 2014; Barnes et al. 2014; Hung et al. 2011). Yoo and Lee (2012) examined the purchase activities of consumers, who have experienced both buying genuine fashion brands and their counterfeits. The study found that positive experiences with genuine brands served as important indicators of future positive purchase intentions for such brands, as well as negative purchase intentions of counterfeit brands (Yoo \& Lee 2012). That is, when consumers have pleasant experiences in visiting official retailers of fashion brands, they become 
less tempted to buy counterfeit products and are more likely to purchase more genuine products. However, the study found that converse did not hold. That is, positive experiences in purchasing counterfeit products were not found to indicate continued patronage of such products. The notion of brand experience in the light of creating experiential value was inherent in the applied work of Pine and Gilmore (1999), who studied the influence of experiential value on consumer buying behaviour. From this study, it is made evident that the more a brand evokes multiple experience dimensions, the more likely it is that consumers will return to the store.

H5: There is a positive relationship between brand experience and purchase intention.

\section{Research methodology}

This study undertook a research approach that is consistent with the positivist paradigm as it attempted to examine the relationships between the dependent and independent variables. Being quantitative in nature, the measurement instrument was compiled from a number of existing scales that were adapted to suit the purpose of the study. Once scale reliability and validity were established, structural equation modelling (SEM) was used to test the model fit, followed by the hypotheses testing and path modelling. SEM was performed using Amos 23 software, and the descriptive statistics were obtained through SPSS 23 software.

\section{Sample and data collection}

The data collection was conducted among 501 black women in South Africa, considered to be part of the middle-class. By means of systematic sampling, every fourth individual from a pre-screened panel of 2000 elements were selected for questionnaire completion. This sample size was calculated in the following way: from an estimate population of 3.4 million black middle-class women in Johannesburg, an allowance of a 95\% confidence level was allowed, using a 5\% confidence interval. By means of the Raosoft ${ }_{\circledast}$ sample size calculator, the researcher has estimated a sample size of at least 384. To decrease possible sampling errors, a sample of 501 participants was surveyed.

\section{Measurement instrument and questionnaire design}

Research scales were operationalised on the basis of past research in the same field of study, and adequate modifications were applied in order to fit the current research context and purpose. All scales were measured using a 7-point Likert scale. For the first variable, store environment, a modified version of Baker, Grerral and Parasuraman's (1994) scale was used. Brand experience was measured using a scale adapted from Sahin, Zehir and Kitapçi (2011). To measure brand attitude, Martinez and Chernatony's (2004) scale was used, and lastly, purchase intention was measured using Shukla's (2011) purchase intention scale.

\section{Data analysis and results}

This section provides an overview of the respondent profile, the scale accuracy analysis, the model fit and hypotheses results.

\section{Respondent profile}

The profile of the participants is presented in Table 1 followed by a discussion.

The findings in Table 1 indicate that the majority of the respondents (40\%) have a diploma, whereas $26 \%$ and $24 \%$ have a graduate degree and a professional certificate, respectively. The remainder, which accounts for 10\%, has a postgraduate degree. Fifty-two per cent of the respondents are between the ages of 25 and 34 years, with $26 \%$ between the ages of 17 and 24 years and 22\% being older than 34 years of age. The analysis further indicates that $53 \%$ have a monthly household income of between R8001 and R40 000, with 19\% earning less than R8000 per month and 14\% earning above R40 000. More specifically, from the portion of respondents earning between R8001 and R40 000, three relatively equal clusters are evident, with incomes ranging between R8001 and R16 000 (21\%), followed by those between R16 001 and R25 000 (16\%), with 16\% earning between R25001 and R40 000. In terms of occupation, almost $60 \%$ are full-time employed and working for a company. Fourteen per cent of the respondents are students or trainees, whereas $10 \%$ are seeking employment. The remainder, which accounts for a relatively small portion, either works part-time or is self-employed.

\section{Scale accuracy analysis}

The scale accuracy analysis is presented in Table 2 followed by a discussion of the measurement scale reliability and validity.

TABLE 1: Sample demographic profile.

\begin{tabular}{|c|c|c|c|c|c|}
\hline Education & Frequency & $\%$ & Age & Frequency & $\%$ \\
\hline Diploma & 193 & 40 & $17-24$ & 130 & 26 \\
\hline Graduate degree & 129 & 26 & $25-34$ & 261 & 52 \\
\hline Postgraduate & 50 & 10 & $35-44$ & 95 & 19 \\
\hline Professional certificate & 131 & 24 & $45-54$ & 10 & 2 \\
\hline Total & 501 & 100.0 & $55-65$ & 5 & 1 \\
\hline Income & Frequency & $\%$ & Occupation & Frequency & $\%$ \\
\hline R1-R4000 & 56 & 11 & $\begin{array}{l}\text { Trainee, Apprentice, } \\
\text { Student }\end{array}$ & 68 & 14 \\
\hline R4001-R8000 & 40 & 8 & $\begin{array}{l}\text { Working full-time } \\
\text { (for a company) }\end{array}$ & 296 & 59 \\
\hline R8001-R16 000 & 105 & 21 & $\begin{array}{l}\text { Working full-time } \\
\text { (self-employed) }\end{array}$ & 22 & 4 \\
\hline R16 001-R25 000 & 81 & 16 & $\begin{array}{l}\text { Working part-time } \\
\text { (for a company) }\end{array}$ & 39 & 8 \\
\hline R25 001-R40 000 & 79 & 16 & $\begin{array}{l}\text { Working part-time } \\
\text { (self-employed) }\end{array}$ & 12 & 3 \\
\hline R40 001-R60 000 & 45 & 9 & Homemaker & 6 & 1 \\
\hline R60 001-R100 000 & 17 & 3 & $\begin{array}{l}\text { Unemployed - } \\
\text { seeking work }\end{array}$ & 52 & 10 \\
\hline R100 001 & 11 & 2 & Retired, pensioner & 6 & 1 \\
\hline Prefer not to answer & 67 & 14 & - & - & - \\
\hline Total & 501 & 100.0 & Total & 501 & 100.0 \\
\hline
\end{tabular}


TABLE 2: Accuracy analysis statistics.

\begin{tabular}{|c|c|c|c|c|c|c|c|c|c|c|c|}
\hline \multirow{2}{*}{\multicolumn{2}{|c|}{ Research construct }} & \multicolumn{4}{|c|}{ Descriptive statistics } & \multicolumn{2}{|c|}{ Cronbach's test } & \multirow{3}{*}{$\begin{array}{c}\text { CR Value } \\
0.808\end{array}$} & \multirow{3}{*}{$\begin{array}{c}\text { AVE Value } \\
0.383\end{array}$} & \multirow{3}{*}{$\begin{array}{c}\begin{array}{c}\text { Highest shared } \\
\text { variance }\end{array} \\
0.296\end{array}$} & \multirow{3}{*}{$\begin{array}{c}\begin{array}{c}\text { Factor } \\
\text { loading }\end{array} \\
0.702\end{array}$} \\
\hline & & \multicolumn{2}{|c|}{ Mean value } & \multicolumn{2}{|c|}{ Standard deviation } & \multirow{2}{*}{$\begin{array}{c}\text { Item-total } \\
0.587\end{array}$} & \multirow{2}{*}{$\begin{array}{c}\alpha \text { value } \\
0.801\end{array}$} & & & & \\
\hline$\overline{\mathrm{STE}}$ & STE1 & 5.491 & 4.780 & 1.282 & 1.521 & & & & & & \\
\hline & STE2 & 5.253 & - & 1.386 & - & 0.545 & - & - & - & - & 0.681 \\
\hline & STE4 & 4.675 & - & 1.585 & - & 0.591 & - & - & - & - & 0.666 \\
\hline & STE6 & 4.868 & - & 1.506 & - & 0.606 & - & - & - & - & 0.700 \\
\hline & STE7 & 4.533 & - & 1.528 & - & 0.600 & - & - & - & - & 0.616 \\
\hline & STE8 & 4.198 & - & 1.685 & - & 0.352 & - & - & - & - & 0.372 \\
\hline & STE10 & 4.441 & - & 1.673 & - & 0.500 & - & - & - & - & 0.522 \\
\hline \multirow[t]{9}{*}{$\mathrm{BE}$} & BE1 & 5.433 & 5.707 & 1.440 & 1.332 & 0.608 & 0.911 & 0.911 & 0.933 & 0.504 & 0.621 \\
\hline & BE3 & 5.481 & - & 1.327 & - & 0.601 & - & - & - & - & 0.598 \\
\hline & BE4 & 5.854 & - & 1.187 & - & 0.728 & - & - & - & - & 0.795 \\
\hline & BE5 & 5.816 & - & 1.345 & - & 0.670 & - & - & - & - & 0.704 \\
\hline & BE6 & 5.798 & - & 1.354 & - & 0.701 & - & - & - & - & 0.751 \\
\hline & BE7 & 6.076 & - & 1.199 & - & 0.673 & - & - & - & - & 0.717 \\
\hline & BE9 & 5.906 & - & 1.300 & - & 0.733 & - & - & - & - & 0.751 \\
\hline & BE10 & 5.623 & - & 1.331 & - & 0.713 & - & - & - & - & 0.711 \\
\hline & BE11 & 5.631 & - & 1.372 & - & 0.730 & - & - & - & - & 0.749 \\
\hline \multirow[t]{5}{*}{ BA } & BA1 & 5.491 & 5.155 & 1.446 & 1.488 & 0.692 & 0.757 & 0.827 & 0.522 & 0.296 & 0.843 \\
\hline & BA2 & 5.112 & - & 1.582 & - & 0.653 & - & - & - & - & 0.883 \\
\hline & BA3 & 4.858 & - & 1.904 & - & 0.184 & - & - & - & - & 0.706 \\
\hline & BA4 & 4.307 & - & 1.123 & - & 0.578 & - & - & - & - & 0.185 \\
\hline & BA5 & 6.006 & - & 1.220 & - & 0.750 & - & - & - & - & 0.765 \\
\hline \multirow[t]{4}{*}{$\mathrm{PI}$} & PI1 & 6.156 & 6.019 & 1.220 & 1.328 & 0.750 & 0.857 & 0.855 & 0.597 & 0.224 & 0.849 \\
\hline & $\mathrm{PI} 2$ & 6.040 & - & 1.320 & - & 0.797 & - & - & - & - & 0.817 \\
\hline & $\mathrm{PI3}$ & 6.008 & - & 1.452 & - & 0.694 & - & - & - & - & 0.718 \\
\hline & $\mathrm{PI} 4$ & 5.874 & - & 1.320 & - & 0.583 & - & - & - & - & 0.697 \\
\hline
\end{tabular}

STE, store environment; $\mathrm{BE}$, brand experience; $\mathrm{BA}$, brand attitude; PI, purchase intention; CR, composite reliability; AVE, average variance extracted; SV, shared variance.

\section{Testing for scale reliability and validity}

To assess reliability and validity of the measurement scales for this study, the Cronbach's alpha coefficient, the composite reliability test and a comparison between the average variance extracted and the highest shared variance were conducted (Table 2). The Cronbach's alpha coefficients ranged from 0.757 to 0.911 exceeding 0.7 as suggested by Nunnally and Bernstein (1994). Composite reliability values ranged from 0.808 to 0.911 which is acceptable as this exceed 0.7 (Hair, Bush \& Ortinau 2009). Most of the average variance extracted values were above 0.5 which is consisted with the 0.5 recommended by Fraering and Minor (2006).

\section{Inter-correlation values}

As indicated in Table 3, the inter-factor correlation values for all paired latent variables were lower than 1.0; this suggested the existence of discriminant validity according to Pooe, Mafini and Loury-Okoumba (2015). Therefore, indicating that each construct is distinct from the other constructs proving existence of heterogeneity (Malhotra 1996). Furthermore, a correlation value between constructs of less than 0.7 is recommended in the empirical literature to confirm the presence of discriminant validity (Nunnally \& Bernstein 1994).

\section{Assessing measurement model fit}

This section presents the analysis of model fit by assessing a number of different indices, so as to ascertain the degree of
TABLE 3: Correlations matrix.

\begin{tabular}{lcccc}
\hline Heading & STE & BE & BA & PI \\
\hline STE & 1 & $0.492^{* *}$ & $0.544 * *$ & $0.320^{* *}$ \\
BE & $0.492^{* *}$ & 1 & $0.506^{* *}$ & $0.381^{* *}$ \\
BA & $0.544^{* *}$ & $0.506 * *$ & 1 & $0.473^{* *}$ \\
PI & $0.320^{* *}$ & $0.381^{* *}$ & $0.473 * *$ & 1 \\
\hline
\end{tabular}

***Correlation is significant at the 0.01 level (2-tailed).

TABLE 4: Model fit summary.

\begin{tabular}{lllllllll} 
Index & $\begin{array}{l}\text { Accepted } \\
\text { threshold } \\
(>\mathbf{0 . 9 )}\end{array}$ & Accepted threshold (>0.9) & & $\begin{array}{l}\text { Accepted } \\
\text { threshold } \\
(>0.06)\end{array}$ \\
\hline Model fit index & CMIN/DF & NFI & RFI & IFI & TLI & CFI & RMSEA \\
Outcome & 1.981 & 0.919 & 0.904 & 0.958 & 0.950 & 0.958 & 0.04 \\
\hline
\end{tabular}

CMIN/DF, NFI, normed fit index; RFI, IFI, incremental fit index; TLI, Tucker-Lewis Index; CFI; RMSEA, root mean square error of approximation.

acceptable or good model fit (Table 4). The following indices are examined: CMIN, the normed fit index (NFI), incremental fit index (IFI), Tucker-Lewis Index (TLI), goodness of fit index (GFI), and the root mean square error of approximation (RMSEA). Because of standardised regression weights being lower than 0.5, STE3, STE5, STE 9, STE12 and BE2 were removed from analysis (Hair et al. 1998). Table 4 presents the results of the model fit indices.

It is evident from Table 4 that all the model fit indices reach the acceptable thresholds. RMSEA is indicated by a value of 0.04 that is below 0.08 as recommended by Hooper, Coughlan and Mullen (2008). CMIN, NFI, RFI, IFI, TLI and CFI all meet the recommended threshold of 9 (McDonald \& Ho 2002). 


\section{Hypotheses testing and path coefficients}

Table 5 presents the results of the hypotheses and path coefficients followed by a discussion.

The results in Table 5 provide clear evidence that four of the five hypotheses are supported. In other words, store environment has a positive influence on both brand attitude (H1) and brand experience (H3). Furthermore, brand attitude has a positive influence on purchase intention (H4), and lastly, brand experience positively influences purchase intention (H5). The relationship between store environment and purchase intention was found to be insignificant and the hypothesis therefore unsupported (H2). Upon examining the estimates, the strongest relationship was found between store environment and brand experience (0.79), followed by store environment and brand attitude (0.69). The weakest relationship was found between brand experience and purchase intention (0.16). Brand attitude had a relatively strong influence on purchase intention (0.42).

\section{Implications of the study}

Derived from the findings, it is clear that the more feasible the store environment, the more likely that consumers will portray a positive attitude towards the brand. Likewise, a pleasant store environment will increase the likelihood that consumers will have a positive brand experience. Consequently, a positive brand attitude and brand experience is likely to increase consumers' purchase intention. Marketing practitioners and retailers should therefore focus on creating a pleasurable store environment by utilising atmospheric cues. For example, the store layout and design is of imperative importance in allowing adequate flow with clear signage for the customers. Furthermore, the window displays must attract the target audience into the store and the visual merchandising must be appealing. Fashion retailers should ensure that the music is suitable to the target audience and the brand image. In such a way, fashion brands can create the ultimate store environment by utilising each of the five senses through a multi-sensory brand approach. By achieving this, fashion retailers will gain financially as customers are more likely to purchase a product and ultimately become loyal to the brand.

\section{Limitations and future research}

There is room for further research in terms of investigating the relationship between store environment and other branding

TABLE 5: Hypotheses results and path coefficients.

\begin{tabular}{|c|c|c|c|c|}
\hline Path coefficient & Hypothesis & Estimate & $p$ & Result \\
\hline $\begin{array}{l}\text { Store environment } \\
\rightarrow \text { Brand attitude }\end{array}$ & $\mathrm{H} 1$ & $0.69 * * *$ & $* * *$ & Supported and significant \\
\hline $\begin{array}{l}\text { Store environment } \\
\rightarrow \text { Purchase intention }\end{array}$ & $\mathrm{H} 2$ & -0.2 & 0.868 & $\begin{array}{l}\text { Unsupported and } \\
\text { insignificant }\end{array}$ \\
\hline $\begin{array}{l}\text { Store environment } \\
\rightarrow \text { Brand experience }\end{array}$ & $\mathrm{H} 3$ & $0.79 * * *$ & $* * *$ & Supported and significant \\
\hline $\begin{array}{l}\text { Brand attitude } \\
\rightarrow \text { Purchase intention }\end{array}$ & $\mathrm{H} 4$ & $0.42 * * *$ & $* * *$ & Supported and significant \\
\hline $\begin{array}{l}\text { Brand experience } \\
\rightarrow \text { Purchase intention }\end{array}$ & H5 & $0.16 * *$ & 0.002 & Supported and significant \\
\hline
\end{tabular}

variables such as brand loyalty, brand awareness and brand satisfaction. It is recommended that future researchers consider other demographic groups as considering only one demographic group could have marginalised the results. Through sampling men and women of different races and classes, future researchers could have useful insights into how consumers respond to the effects of store environment on their intention to purchase a fashion product. This research could possibly have been compromised by financial or time restraints, and future research may benefit from increased funding which could ultimately provide a more in-depth comprehension of the study in question. Lastly, this study may yield different results across other industries that may be of interest to a broader range of retailers.

\section{Conclusion}

This study contributes to literature in the field of fashion retail and multi-sensory branding and provides marketing practitioners with a better understanding of strategies that can be employed to influence consumers' buying behaviour. More specifically, factors such as brand attitude, brand experience and purchase intention can be positively influenced which will result in consumers' purchase intention. The implementation of innovative retail strategies in the fashion industry is therefore of imperative importance to drive sales and increase profit margins. This study therefore highlights the importance of using innovation and creativity to create a competitive advantage within the fashion retail sector.

\section{Acknowledgements Competing interests}

The authors declare that they have no financial or personal relationships which may have inappropriately influenced them in writing this article.

\section{Authors' contributions}

This article was based on the doctoral thesis of M.V.d.V., with R.C. as the supervisor. T.C. assisted with the statistical analysis for the $\mathrm{PhD}$ thesis as well as the statistical analysis for this specific article. M.V.d.V. was responsible for writing the majority of the content for this article, while T.C. conducted the statistical analysis. R.C. was supervising this project.

\section{References}

Anderson, K., Knight, D., Pookulanga, S. \& Josiam, B., 2014, 'Influence of hedonic and utilitarian motivations on retailer loyalty and purchase intention: A Facebook perspective', Journal of Retailing and Consumer Services 21(5), 773-779. https:// doi.org/10.1016/j.jretconser.2014.05.007

Arnold, M. \& Reynolds, K., 2003, 'Hedonic shopping motivations', Journal of Retailing 79(2), 117-125. https://doi.org/10.1016/S0022-4359(03)00007-1

Babin, B.J., Hardesty, D.M. \& Suter, T.A., 2003, 'Colour and shopping intentions: The intervening effect of price fairness and perceived affect', Journal of Business Research 56(7), 541-551. https://doi.org/10.1016/S0148-2963(01)00246-6

Baker, J., Grewal, D. \& Parasuraman, A., 1994, 'The influence of store environment on quality inferences and store image'. Journal of the Academy of Marketing Science 22(4), 328-339.

Barnes, S., Mattsson, J. \& Sørensen, F., 2014, 'Destination brand experience and visitor behavior: Testing a scale in the tourism context', Annals of Tourism Research 48, 121-139. https://doi.org/10.1016/j.annals.2014.06.002 
Beverland, M., Lim, E., Morrison, M. \& Terziovski, M., 2006, 'In-store music and consumer-brand relationships: Relational transformation following experiences of (mis)fit', Journal of Business Research 59(9), 982-989. https://doi.org/10.1016/j. (mis)fit', Journal of Busi

Brakus, J., Schmitt, B. \& Zarantonello, L., 2009, 'Brand experience: What is it? How is it measured? Does it affect loyalty?', Journal of Marketing 73, 52-68.

Brakus, J., Schmitt, B. \& Zarantonello, L., 2014, 'Brand experience: What is it? How do we measure it? And does it affect loyalty?', Journal of Marketing 73, 52-68. https://doi.org/10.1509/jmkg.73.3.52

Clarke, D., Perry, P. \& Denson, H., 2012, 'The sensory retail environment of small fashion boutiques', Journal of Fashion Marketing and Management 16(4), 492-510. https:// doi.org/10.1108/13612021211265872

Dawson, S. \& Kim, M., 2009, 'External and internal trigger cues of impulse buying online', Direct Marketing: An International Journal 3(1), 20-34.

Fraering, M. \& Minor, M.S., 2006, 'Sense of community: An exploratory study of US consumers of financial services', International Journal of Bank Marketing 24(5), 284-306. https://doi.org/10.1108/02652320610681738

Geetha, M., Bharadhwaj, S. \& Piyush, S., 2013, 'Impact of store environment on impulse buying behavior', European Journal of Marketing 47(10), 1711-1732. https://doi.org/10.1108/EJM-03-2011-0110

Gentile, C., Spiller, N. \& Noci, G., 2007, 'How to sustain the customer experience: An overview of experience components that co-create value with the customer' European Management Journal 25(5), 395-410. https://doi.org/10.1016/j.emj. 2007.08.005

Ghodeswar, B.B., 2008, 'Building brand identity in competitive markets: A conceptual model', Journal of Product \& Brand Management 17(1), 4-12. https://doi. org/10.1108/10610420810856468

Hair, J.F., Anderson, R.E., Tatham, R.L. \& Black, W.C., 1998, Multivariate data analysis, 5th edn., Prentice Hall, New York.

Hair, J.F., Bush, R.P. \& Ortinau, D.J., 2009, Marketing research: Within a changing information environment, Juta and Company, Cape Town.

Holmqvist, J. \& Lunardo, R., 2015,' The impact of an exciting store environment on consumer pleasure and shopping intentions', International Journal of Research in Marketing 32(2), 118-131. https://doi.org/10.1016/j.ijresmar.2014.12.001

Hooper, D., Coughlan, J. \& Mullen, M., 2008, Structural equation modelling: Guidelines for determining model fit, Dublin School of Technology, Dublin.

Hu, H. \& Jasper, C., 2006, 'Social cues in the store environment and their impact on store image', International Journal of Retail \& Distribution Management 34(1), 25-48. https://doi.org/10.1108/09590550610642800

Hultén, B., 2011, 'Sensory marketing: The multi-sensory brand-experience concept' European Business Review 23(3), 256-273. https://doi.org/10.1108/095553411 11130245

Hultén, B., Broweus, N. \& Van Dijk, M., 2009, Sensory marketing, Palgrave MacMillan, Hampshire.

Hung, K., Chen, A., Peng, N. \& Hackley, C., 2011, 'Antecedents of luxury brand purchase intention', Journal of Product \& Brand Management 20(6), 457-467. https://doi. org/10.1108/10610421111166603

Hyo, J., Ruoh-Nan, Y. \& Molly, E., 2014, 'Moderating effects of situational characteristics on impulse buying', International Journal of Retail \& Distribution Management 42(4), 298-314. https://doi.org/10.1108/IJRDM-04-2013-0074

Iannone, R., Ingenito, A., Martino, G., Miranda, S., Pepe, C. \& Riemma, S., 2013, 'Merchandise and replenishment planning optimization for fashion retail', International Journal of Engineering Business Management 5(26), 1-14.

Jin, B. \& Kang, J., 2011, 'Purchase intention of Chinese consumers toward a US appare brand: A test of a composite behavior intention model', Journal of Consumer Marketing 28(3), 187-199. https://doi.org/10.1108/07363761111127617

Kamaladevi, B., 2010, 'Customer experience management in retailing', Business Intelligence Journal 3(1), 37-53.

Kim, H., 2012, 'The dimensionality of fashion-brand experience: Aligning consumerbased brand equity approach', Journal of Fashion Marketing and Management 16(4), 418-441. https://doi.org/10.1108/13612021211265827

Kim, J.B., Choo, Y. \& Chang, D.R. (2009). Integrated brand experience through sensory branding and IMC, Design Management Review, 20, 72-81.

Ko, E. \& Megehee, C., 2012, 'Fashion marketing of luxury brands: Recent research issues and contributions', Journal of Business Research 65(10), 1395-1398. https:// doi.org/10.1016/j.jbusres.2011.10.004

Kumar, A. \& Kim, Y., 2014, 'The store-as-a-brand strategy: The effect of store environment on customer responses', Journal of Retailing and Consumer Services 21(5), 685-695. https://doi.org/10.1016/j.jretconser.2014.04.008

Lam, S., 2001, 'The effects of store environment on shopping behaviors: A critical review', Advances in Consumer Research 28, 190-197.

Lu, L., Chang, W. \& Chang, H., 2014, 'Consumer attitudes toward blogger's sponsored recommendations and purchase intention: The effect of sponsorship type, product type, and brand awareness', Computers in Human Behavior 34, 258-266. https://doi.org/10.1016/j.chb.2014.02.007
Lunardo, R. \& Mbengue, A., 2013, 'When atmospherics lead to inferences of manipulative intent: Its effects on trust and attitude', Journal of Business Research manipulative intent: Its effects on trust and attitude', Journal of

Malhotra, N.K., 1996, Marketing research: An applied orientation, 2nd edn., Simon \& Schuster, New York.

Martinez, E. \& Chernatony, L., 2004, 'The effect of brand extension strategies upon brand image', Journal of Consumer Marketing 21(1), 39-50. https://doi. org/10.1108/07363760410513950

McDonald, R.P. \& Ho, M.H.R., 2002, 'Principles and practice in reporting structura equation analyses', Psychological Methods 7(1), 64. https://doi.org/10.1037/1082 989X.7.1.64

Michon, R., Yu, H., Smith, D. \& Chebat, J.C., 2007, 'The shopping experience of female fashion leaders', International Journal of Retail and Distribution Management 35(6), 488-501. https://doi.org/10.1108/09590550710750359

Moore, D., 2014, 'Is anticipation delicious? Visceral factors as mediators of the effect of olfactory cues on purchase intentions', Journal of Business Research 67(9), 2045-2051. https://doi.org/10.1016/j.jbusres.2013.10.005

Nunnally, J.C. \& Bernstein, I.H., 1994, 'The assessment of reliability', Psychometric Theory 3(1), 248-292.

Park, H.H., Jeon, J.O. \& Sullivan, P., 2014, 'How does visual merchandising in fashion retail stores affect consumers' brand attitude and purchase intention?', The International Review of Retail, Distribution and Consumer Research 25(1), 1-18.

Pine, B.J. \& Gilmore, J.H., 1999, The experience economy: Work is theatre and every business a stage, Harvard Business School Press, Boston, MA.

Ponsonby-McCabe, S. \& Boyle, E., 2006, 'Understanding brands as experiential spaces: Axiological implications for marketing strategists', Journal of Strategic Marketing 14(2), 175-189. https://doi.org/10.1080/10427710600662983

Pooe, D., Mafini, C. \& Loury-Okoumba, V.W., 2015, 'The influence of information sharing, supplier trust and supplier synergy on supplier performance: The case of small and medium enterprises', Journal of Transport and Supply Chain Management 9(1), 1-11. https://doi.org/10.4102/jtscm.v9i1.187

Sahin, A., Zehir, C. \& Kitapci, H., 2011, 'The effects of brand experiences, trust and satisfaction on building brand loyalty: An empirical research on global brands', In the Proceedings of 7 th International Strategic Management Conference, Procedia - Social and Behavioural Sciences 24, 1288-1301. https://doi.org/ 10.1016/j.sbspro.2011.09.143

Schmitt, B.H., 1999, 'Experiential marketing', Journal of Marketing Management, 15(1), 53-67. https://doi.org/10.1362/026725799784870496

Schmitt, B.H. \& Rogers, D.L. (eds.), 2008, Handbook on brand and experience management, Edward Elgar, Cheltenham, UK.

Shamim, A. \& Butt, M., 2013, 'A critical model of brand experience consequences', Asia Pacific Journal of Marketing and Logistics 25(1), 102-117. https://doi.org/ 10.1108/13555851311290957

Shukla, P., 2011, 'Impact of interpersonal influences, brand origin and brand image on luxury purchase intentions: Measuring interfunctional interactions and crossnational comparison', Journal of World Business 4692, 242-252. https://doi.org/ 10.1016/j.jwb.2010.11.002

Tendai, M. \& Crispen, C., 2009, 'In-store shopping environment and impulse buying', African Journal of Marketing Management 1(4), 102-108.

Tong, X. \& Hawley, J.M., 2009, 'Measuring customer-based brand equity: Empirical evidence from the sportswear market in China', Journal of Product \& Brand Management 18(4), 262-271. https://doi.org/10.1108/10610420910972783

Unilever Institute of Strategic Marketing, 2013, Black middle class doubles in eight years, viewed 08 June 2014, from http://www.uctunileverinstitute.co.za

Valenti, C. \& Riviere, J., 2008, The concept of sensory marketing, Halmstad University Press, Halmstad.

Vieira, V., 2013, 'Stimuli-organism-response framework: A meta-analytic review in the store environment', Journal of Business Research 66(9), 1420-1426. https://doi. store environment', Journal of Busine
org/10.1016/j.jbusres.2012.05.009

Wang, C. \& Ha, S., 2011, 'Store attributes influencing relationship marketing: A study of department stores', Journal of Fashion Marketing and Management: An

Wu, S. \& Lo, C., 2009, 'The influence of core-brand attitude and consumer perception on purchase intention towards extended product', Asia Pacific Journal of Marketing and Logistics 21(1), 174-194. https://doi.org/10.1108/13555850910926317

Yoo, B. \& Lee, S., 2012, 'Asymmetrical effects of past experiences with genuine fashion luxury brands and their counterfeits on purchase intention of each', Journal of Business Research 65(10), 1507-1515. https://doi.org/10.1016/j.jbusres.2011. 10.018

Yoon, S. \& Park, J., 2012, 'Do sensory ad appeals influence brand attitude?', Journa of Business Research 65(11), 1534-1542. https://doi.org/10.1016/j.jbusres.2011. 02.037

Zenker, S. \& Rütter, N., 2014, 'Is satisfaction the key? The role of citizen satisfaction, place attachment and place brand attitude on positive citizenship behavior', Cities 38, 11-17. https://doi.org/10.1016/j.cities.2013.12.009 